\title{
Large granular lymphocytosis with severe neutropenia following ipilimumab therapy for metastatic melanoma
}

\author{
Guoqing Wei ${ }^{1,2 \dagger}$, Uzoma Nwakuche ${ }^{1 \dagger}$, Gustavo Cadavid ${ }^{1}$, Asim Ajaz, Karen Seiter and Delong Liu ${ }^{1 *}$
}

To the editor

Cytotoxic T-lymphocyte antigen-4 (CTLA-4), a molecule present on activated $\mathrm{T}$ cells, is a homologue of CD28 that inhibits B7 co-stimulatory molecules expressed on mature antigen presenting cells. Ipilimumab is a fully humanized monoclonal antibody against CTLA-4 [1]. Ipilimumab is FDA approved in the United States for treatment of unresectable or metastatic melanoma [1,2]. We report the first case of large granular lymphocytosis with severe neutropenia following ipilimumab therapy.

A 74 year old female presented with relapsed melanoma in the left lower extremity in Sept 2009. She was treated with temozolomide. In July 2010, she developed metastatic melanoma. She was enrolled onto a clinical trial and treated with ipilimumab on Sept 16, 2010 and October 7,2010 at $3 \mathrm{mg} / \mathrm{kg}$ (232 $\mathrm{mg}$ per treatment) q3wks. Her baseline CBC was normal. At the start of the third dose, there was a significant decline in the patient's WBC count. Therefore ipilimumab was stopped. The patient was admitted on November 2, 2010 with fever, malaise and generalized weakness. She was noted to have Hgb $6.2 \mathrm{G} / \mathrm{dL}$, WBC $1.3 \times 10^{6} / \mathrm{L}$ with no neutrophils, and platelet count of $158 \times 10^{6}$ /L. The patient had a bone marrow evaluation which showed mildly hypercellular cellular marrow with marked myeloid hypoplasia/aplasia, relative erythroid hyperplasia and mild megakaryocytic atypia. Karyotype analysis demonstrated $46 \mathrm{XX}$, but FISH analysis showed a $5 \mathrm{q} 31$ deletion with EGR1 gene deletion in $14 \%$ of the cells. Flow cytometry study showed $46 \%$

\footnotetext{
* Correspondence: DELONG_LIU@NYMC.EDU

† Contributed equally

'Division of Hematology and Oncology, New York Medical College and

Westchester Medical Center, Valhalla, NY 10595, USA

Full list of author information is available at the end of the article
}

T-cells with $20 \%$ large granular lymphocytes and $12 \%$ NK cells. A T-cell receptor gene study by Genzyme showed clonal $\mathrm{T}$-cell receptor gamma gene rearrangement. These findings were consistent with myelodysplasia and large granular lymphocytosis with severe neutropenia. In addition to broad-spectrum antibiotics and G-CSF, the patient was given IVIG without significant response. The CBC on Nov 17 was WBC 0.8 , Hgb 8.9, and Platelets 271. CT scans revealed bilateral loculated pleural effusion for which she had thoracentesis. The patient was started on treatment on Nov 18, 2010 with IV methylprednisolone $1 \mathrm{mg} / \mathrm{kg} \mathrm{q} 12 \mathrm{~h}$, and equine ATG at $15 \mathrm{mg} / \mathrm{kg}$ daily $\times 4$ days, as well as cyclosporine $2.5 \mathrm{mg} / \mathrm{kg}$ twice daily. G-CSF and antibiotics were continued. The WBC rose to 2.6 the day after ATG was completed (Table 1). Two days later, her WBC was 15.3. G-CSF was stopped. Her general condition improved gradually. She was discharged 11 days later. She remained on cyclosporine and low dose prednisone. Three months later, she remained only on low dose prednisone. Her CBC showed WBC 12.1, Hgb 11.9, and Platelets 259 at last follow-up visit on Feb 23, 2011.

The most common adverse events associated with ipilimumab are immune-related, including enterocolitis, hepatitis, dermatitis and hypophysitis. Severe hematological toxicity is rare. One case of severe autoimmune-related neutropenia was reported and the patient responded rapidly to IVIG infusion, but not to steroids [3]. This case of large granular lymphocytosis with severe neutropenia did not respond to IVIG and steroids, but had a rapid response to ATG, steroids, and cyclosporine immunosuppressive therapy. It is unclear whether the myelodysplasia findings on the bone marrow biopsy were related to the ipilimumab

(c) 2012 Wei et al; licensee BioMed Central Ltd. This is an Open Access article distributed under the terms of the Creative Commons 
Table 1 Complete Blood Counts of the Patient

\begin{tabular}{lllll}
\hline Date & $\begin{array}{l}\text { WBC } \\
\left.\left(\times 10^{9}\right) / \mathbf{L}\right)\end{array}$ & $\begin{array}{l}\text { ANC } \\
\left.\left(\times 10^{9}\right) / \mathbf{L}\right)\end{array}$ & $\begin{array}{l}\text { Hgb } \\
(\times \mathbf{g} / \mathbf{L})\end{array}$ & $\begin{array}{l}\text { PIt } \\
\left.\left(\times 10^{9}\right) / \mathbf{L}\right)\end{array}$ \\
\hline $11 / 17 / 2010$ & 0.8 & & 8.9 & 271 \\
$11 / 18 / 2010$ & 0.9 & & 9.0 & 280 \\
$11 / 19 / 2010$ & 0.1 & & 8.3 & 142 \\
$11 / 20 / 2010$ & 0.3 & & 8.1 & 90 \\
$11 / 21 / 2010$ & 0.7 & & 8.8 & 92 \\
$11 / 22 / 2010$ & 2.6 & 1.2 & 8.5 & 60 \\
$11 / 23 / 2010$ & 15.3 & 6.7 & 8.7 & 70 \\
$11 / 24 / 2010$ & 30.3 & 19.4 & 8.2 & 73 \\
$11 / 25 / 2010$ & 35.9 & & 7.8 & 55 \\
$11 / 27 / 2010$ & 28.4 & 25.8 & 9.7 & 43 \\
$11 / 28 / 2010$ & 23.6 & 20.5 & 10.1 & 41 \\
$11 / 30 / 2010$ & 15.0 & 13.8 & 8.5 & 77 \\
$12 / 1 / 2010$ & 12.4 & & 8.8 & 82 \\
$12 / 2 / 2010$ & 8.8 & 7.2 & 7.9 & 61 \\
$12 / 17 / 2010$ & 2.7 & 1.6 & 9.8 & 59 \\
$12 / 21 / 2010$ & 7.0 & 5.3 & 10.8 & 157 \\
$2 / 17 / 2011$ & 6.5 & 5.6 & 10.1 & 194 \\
$2 / 23 / 2011$ & 12.1 & 10.3 & 11.9 & 259 \\
\hline Ab & & & 93 \\
\hline
\end{tabular}

Abbreviations: WBC: white blood cell; ANC: absolute neutrophils count; $\mathrm{Hgb}$ : hemoglobin; Plt: platelet.

therapy or to previous chemotherapy with temozolomide.

\section{Acknowledgements}

This study was supported in part by NYMC Blood Disease Fund (DL).

\section{Author details}

'Division of Hematology and Oncology, New York Medical College and Westchester Medical Center, Valhalla, NY 10595, USA. ${ }^{2}$ Bone Marrow Transplantation Center, the First Affiliated Hospital, Zhejiang University School of Medicine, Hangzhou 310003, China.

\section{Authors' contributions}

GW and UN contributed equally to the study. All authors participated in concept design, data collection and analysis, drafting and critically revising the manuscript. All authors read and approved the final manuscript.

\section{Competing interests}

The authors declare that they have no competing interests.

Received: 13 February 2012 Accepted: 26 March 2012 Published: 26 March 2012

\section{References}

1. Lee B, Mukhi N, Liu D: Current management and novel agents for malignant melanoma. J Hematol Oncol 2012, 5:3.

2. Hodi FS, O'Day SJ, McDermott DF, Weber RW, Sosman JA, Haanen JB, Gonzalez R, Robert C, Schadendorf D, Hassel JC, et al: Improved survival with ipilimumab in patients with metastatic melanoma. $N$ Engl J Med 2010, 363(8):711-723.

3. Akhtari M, Waller EK, Jaye DL, Lawson DH, Ibrahim R, Papadopoulos NE, Arellano ML: Neutropenia in a patient treated with ipilimumab (antiCTLA-4 antibody). J Immunother 2009, 32(3):322-324. doi:10.1186/2162-3619-1-3

Cite this article as: Wei et al.: Large granular lymphocytosis with severe neutropenia following ipilimumab therapy for metastatic melanoma. Experimental Hematology \& Oncology 2012 1:3.

\section{Submit your next manuscript to BioMed Central and take full advantage of:}

- Convenient online submission

- Thorough peer review

- No space constraints or color figure charges

- Immediate publication on acceptance

- Inclusion in PubMed, CAS, Scopus and Google Scholar

- Research which is freely available for redistribution

Submit your manuscript at www.biomedcentral.com/submit 